\title{
Routine and rapid enzyme linked immunosorbent assays for circulating anti-glomerular basement membrane antibodies
}

\author{
JANICE WHEELER, * JUDY SIMPSON, † A R MORLEY* \\ From the Departments of ${ }^{*}$ Histopathology and $\nmid$ Medical Statistics, University of Newcastle upon Tyne
}

SUMMARY Microtitre plate modifications of the original tube enzyme linked immunosorbent assay (ELISA) of Wheeler and Sussman were used for the routine and rapid assays of anti-glomerular basement membrane antibodies in human sera. In a prospective study of 238 sera from 200 patients, the routine assay (about 24 hours) detected circulating antibodies in seven sera from three patients with active anti-glomerular basement membrane disease. The remaining sera, from patients with a variety of other glomerulonephropathies, were negative by the assay. The rapid assays took less than four hours, and in a retrospective study, detected anti-glomerular basement membrane antibodies in a range of 15 positive sera, with a level of discrimination similar to that observed in the routine assay and with no false positive/negative results.

The diagnosis of anti-glomerular basement membrane (GBM) disease can be confirmed by the demonstration of anti-glomerular basement membrane antibodies in the serum. Various methods have been applied, including gel diffusion, ${ }^{\prime}$ passive haemagglutination, ${ }^{23}$ and indirect immunofluorescence, ${ }^{14}$ but all lack sensitivity or specificity, or both. More recently, radioimmunoassay $^{5-7}$ and enzyme linked immunosorbent assay (ELISA) ${ }^{8-11}$ techniques have been described, which, although more sensitive, are also limited. Radioimmunoassay is limited by the short half life of the reagents, the need for expensive equipment, and the strict regulatory controls on the use of radioisotopes. In contrast, ELISA uses stable reagents and is inexpensive and simple to perform, but difficulties may be encountered in controlling coating of the antigen to plastic.

In 1981 Wheeler and Sussman described an ELISA for the quantitative determination of anti-glomerular basement membrane antibodies in human sera. ${ }^{8}$ The method, which used disposable polystyrene tubes as the supporting medium, was both sensitive and reproducible. Several features of the assay, however, made it unsuitable as a routine laboratory test: it required large volumes of reagents, the use of tubes made the technique laborious, and the assay was long, requiring about two and a half days to obtain a result. In 1985 a microtitre plate modification of the method

Accepted for publication 18 August 1987 was reported by Weber $e a^{\prime \prime}{ }^{11}$ which, although specific, sensitive, and reproducible, was still long, requiring about 36 hours under optimal conditions.

In this report microtitre plate modifications of the original tube ELISA of Wheeler and Sussman ${ }^{8}$ for routine and rapid assays of anti-glomerular basement membrane antibodies in human sera are described. Both systems use disposable, flexible, polyvinylchloride (PVC) microtitre plates as the supporting medium.

\section{Material and methods}

Disposable, flexible, PVC microtitre plates (code M29) were purchased from Dynatech Laboratories Limited, Sussex. The plates contain 96 flat bottomed wells in the usual configuration of 8 rows $\times 12$ columns.

Highly purified, lyophilised Clostridium histolyticum collagenase was obtained from Cambrian Chemicals Limited, Surrey and stored at $4^{\circ} \mathrm{C}$.

The following buffers were prepared according to Gomori $^{12}: 0 \cdot 1 \mathrm{M}$ Tris-acetate (pH 7.4) containing $0.005 \mathrm{M}$ calcium acetate: $0.05 \mathrm{M}$ carbonate buffer $(\mathrm{pH}$ 9.8). Phosphate buffered saline/Tween 20 (PBST), used for all washing procedures and certain dilutions in the ELISA, comprised $0.01 \mathrm{M}$ phosphate buffered saline (pH 7.1) containing $0 \cdot 15 \%$ Tween 20 .

Protein concentrations were determined by the Hartree ${ }^{13}$ modification of the Lowry method, with bovine serum albumin as a reference standard. 
Glomerular basement membranes were prepared from human cadaver kidneys ${ }^{14}$ and stored at $-20^{\circ} \mathrm{C}$ as lyophilised preparations. To prepare a soluble antigen for use in the ELISA the lyophilised glomerular basement membrane was suspended in $0.1 \mathrm{M}$ Trisacetate buffer ( $\mathrm{pH} 7.4$ ) containing $0.005 \mathrm{M}$ calcium acetate, to a concentration of $25 \mathrm{mg} / \mathrm{ml}$. Collagenase was added to $0.7 \%(\mathrm{w} / \mathrm{w})$ of the glomerular basement membrane and the mixture was incubated at $37^{\circ} \mathrm{C}$ for 24 hours. More collagenase was then added, equal to $0.35 \%$ of the initial weight of the glomerular basement membrane and incubation was continued for a further 24 hours. The mixture was then centrifuged at $3000 \mathrm{~g}$ for 15 minutes and the soluble collagenase digest was stored in $30 \mu \mathrm{l}$ aliquots at $-20^{\circ} \mathrm{C}$.

Goat antihuman IgG (chain specific) alkaline phosphatase conjugate, $F\left(a b^{1}\right)_{2}$ fragment, was purchased from Sigma London Chemical Company Limited, Surrey, and stored at $4^{\circ} \mathrm{C}$.

The conjugate substrate was p-nitrophenylphosphate (NPP), which was obtained in tablet form from Sigma London Chemical Company Limited and stored at $-20^{\circ} \mathrm{C}$. NPP was dissolved in $0.05 \mathrm{M}$ carbonate buffer (pH 9.8) containing $0.005 \mathrm{M} \mathrm{MgCl}_{2}$. $6 \mathrm{H}_{2} \mathrm{O}$, to a concentration of $1 \mathrm{mg} / \mathrm{ml}$ for use in the assay. This solution was prepared fresh daily.

Sera positive for anti-glomerular basement membrane antibody from two patients with active antiglomerular basement membrane disease were used as positive sera and normal human serum was used as a negative serum. These positive sera, normal human serum, and all patients' sera for assay were stored at $-20^{\circ} \mathrm{C}$ in $300 \mu$ l aliquots; wherever possible, a fresh aliquot was used for each assay.

\section{ROUTINE (OPTIMAL) ELISA METHOD}

1 Collagenase digest was diluted with $0.05 \mathrm{M}$ carbonate buffer ( $\mathrm{pH} 9.8$ ) containing $0.1 \%$ sodium azide, to a protein concentration of $10 \mu \mathrm{g} / \mathrm{ml}$. Antigen preparation $(150 \mu \mathrm{l})$ was added to each of the interior 60 wells of the microtitre plate. The outer edge of 36 wells was filled only with $150 \mu$ l of PBST to minimise the problems of "edge effect". The plate was incubated in a covered incubation tray at $37^{\circ} \mathrm{C}$ for three hours and either used immediately or stored in the incubation tray at $4^{\circ} \mathrm{C}$ for use within the following week.

2 The antigen solution was removed and the plate washed three times with PBST.

3 Control and test sera were diluted with PBST and $150 \mu \mathrm{l}$ of each serum dilution was added to each well. Each serum dilution was assayed in triplicate in adjacent wells in the same column of a plate and the plate was incubated for two hours at $25^{\circ} \mathrm{C}$.

4 After three washes with PBST $150 \mu$ l of conjugate, diluted 1 in 1000 with PBST, was added to each well and the plate was incubated overnight at $25^{\circ} \mathrm{C}$.
5 Excess conjugate was washed out and $150 \mu \mathrm{l}$ of conjugate substrate was added to each well.

6 After incubation at $25^{\circ} \mathrm{C}$ for 15 minutes the reaction was terminated by the addition of $30 \mu \mathrm{l}$ of $\stackrel{\overrightarrow{\mathrm{S}}}{\overrightarrow{\mathrm{C}}}$ $3 \mathrm{M}$ sodium hydroxide solution to each well.

7 The absorbances of all solutions were read at $\frac{C}{0}$ $405 \mathrm{~nm}$ using a Titertek Multiskan MCC ELISA $\overline{\bar{\sigma}}$ reader (Flow Laboratories) in conjunction with a BBC $\widetilde{\Phi}$ B Microcomputer and a Plateskan program from $I Q$ (Bio) Limited, Cambridge.

In addition to known positive and negative sera, a $\overrightarrow{0}$ direct conjugate control and a substrate blank were $\overrightarrow{\vec{\omega}}$ included on each plate. The wells for the direct $\omega$ conjugate control were filled with $150 \mu \mathrm{l}$ of PBST옹 instead of serum in step 3 and provided a control on the extent of non-specific conjugate binding. The $\vec{\sim}$ substrate blank was obtained by substituting PBST for $?$ serum in step 3 and conjugate in step 4 and provided $a \underset{\mathcal{G}}{ }$ control on spontaneous hydrolysis of the conjugate 0 substrate.

To calculate the results the mean absorbance of the $\vec{T}$ triplicate direct conjugate control readings was sub- $\frac{1}{0}$ tracted from the triplicate absorbance of each serum dilution.

\section{RAPID ELISA METHOD}

All reagent concentrations and incubation temperatures in the rapid ELISA method were the same as those used in the routine (optimal) method stated above, but different incubation times were used for the various stages (steps 1, 3, 4, and 6) of the assay.

\section{METHOD OF ELISA QUANTITATION}

A standard curve was constructed with the known positive sera, which were assayed at seven dilutions, $\stackrel{?}{\rightleftarrows}$ ranging from 1 in 1000 to 1 in 100 . This dilution range was calibrated to represent 10 to 100 arbitrary응 antibody units of activity and thus provided a standard curve of absorbance against antibody activity. 3 Over this range, the relation between absorbance and $\log$ arbitrary antibody units was roughly linear, so the equation of the standard curve was obtained by linear 0 regression.

Test sera and normal human serum were assayed at $\frac{D}{O}$ dilutions of 1 in 100 and the regression equation was used to estimate anti-glomerular basement membrane of antibody activity from the absorbances obtained. $N$ Values of $<10$ arbitrary antibody units were obtained by simple extrapolation of the curve.

To investigate edge effects - that is, higher absorbances in the peripheral wells, uniformity experiments were conducted with seven plates. All 96 wells were $\cong$ treated identically, using the same known positive serum. The absorbances were analysed by two way analysis of variance, to test for differences between $\stackrel{\mathbb{D}}{ }$ columns and between rows on a plate. 
All other analyses were performed on the $\log _{10}$ (antiglomerular basement membrane antibody activity) estimates, obtained from the standard curve regression equations, to allow for variations in the assay conditions. Sources of variability in measurements were examined by estimating components of variance for each serum from triplicate measurements made on each of three plates on each of three successive weeks. The variance of the 27 measurements is estimated by $\mathrm{S}_{\mathrm{E}}{ }^{2}+\mathrm{S}_{\mathrm{P}}{ }^{2}+\mathrm{S}_{\mathrm{W}}{ }^{2}$, where $\mathrm{S}_{\mathrm{E}}{ }^{2}$ is the average variability between triplicates-that is, the average intra-assay variability; $\mathrm{S}_{\mathrm{P}}{ }^{2}$ is the additional variability due to differences between plates assayed on the same day; and $S_{w}{ }^{2}$ is the extra variability from differences in conditions from one week to another. Both $\mathrm{S}_{\mathrm{p}}{ }^{2}$ and $\mathrm{S}_{\mathrm{w}}{ }^{2}$ contribute to interassay variability of assays performed on different days. Coefficients of variation (CVs) were obtained by dividing the square root of each of these components of variance by the mean $\log _{10}$ (antiglomerular basement membrane antibody activity).

\section{Results}

STANDARDISATION OF ROUTINE (OPTIMAL) ELISA The effect of varying the concentration of antigen during the preparation of the immunoadsorbent is shown in fig 1 . The antigen concentration ranged from 0.01 to $100 \mu \mathrm{g} / \mathrm{ml}$ and the optimal coating concentration was $10 \mu \mathrm{g} / \mathrm{ml}$. The reaction with normal human serum at all antigen concentrations was minimal.

The effect of the duration of antibody incubation, with varying dilutions of positive serum and normal human serum is shown in fig 2 . With the positive serum there was an increase in absorbance with time, which, with the higher concentrations of serum, reached a plateau between one and three hours. Two hours was therefore selected as the optimal antibody incubation time. Again the reactions with normal human serum were minimal.

The optimal incubation time with conjugate was investigated in a similar manner, varying the incubation time from one to 21 hours (fig 3). The reaction with positive serum showed a steady increase in absorbance up to five hours, which slowly increased if the system was left for 21 hours. For practical purposes, overnight incubation with conjugate was selected. Again, there was only a minimal reaction with normal human serum.

With the optimal conditions of antigen concentration and antibody and conjugate incubation times, a standard curve was obtained with positive serum. A representative standard curve is illustrated in fig 4 .

\section{EDGE-EFFECTS}

All seven uniformity experiments showed highly significant $(p<0.0001)$ column and row effects, with a similar variety of patterns of variation over a plate to that reported by Stemshorn et al. ${ }^{15}$ The usual pattern was of increasing absorbances from the centre of the plate toward all four edges, but some plates showed a left to right or top to bottom downward gradient or a concentration of high absorbances in one corner. The CV ranged from 6.0 to $12.7 \%$ (mean $8.2 \%$ ). When the outer 36 wells were excluded from analysis, column and row effects remained highly significant for all but one plate, but the $\mathrm{CV}$ was much lower, ranging from 2.2 to $8.9 \%$ (mean $4.7 \%$ ). Typically, the CV was thus

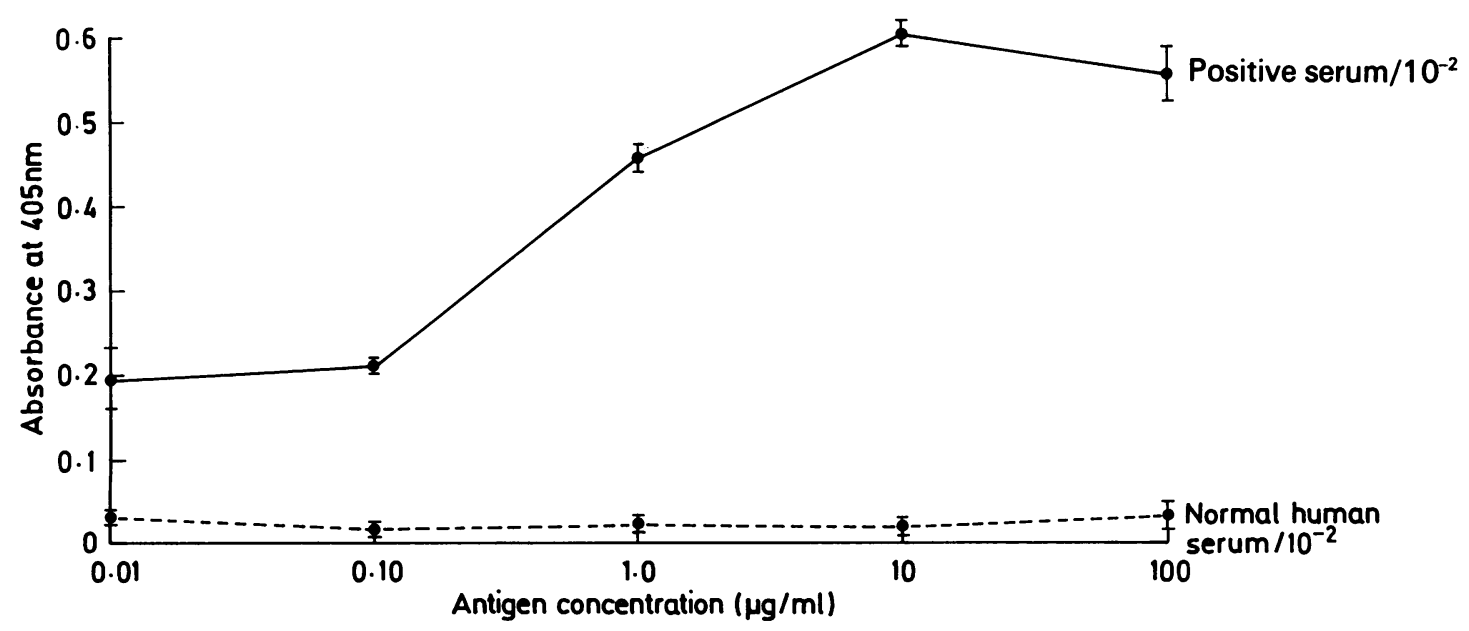

Fig 1 Titration for optimal antigen adsorption. Positive serum $10^{-2}=$ known positive anti-glomerular antibody containing serum at 1 in 100 dilution. Normal human serum $10^{-2}(1$ in 100) dilution. 


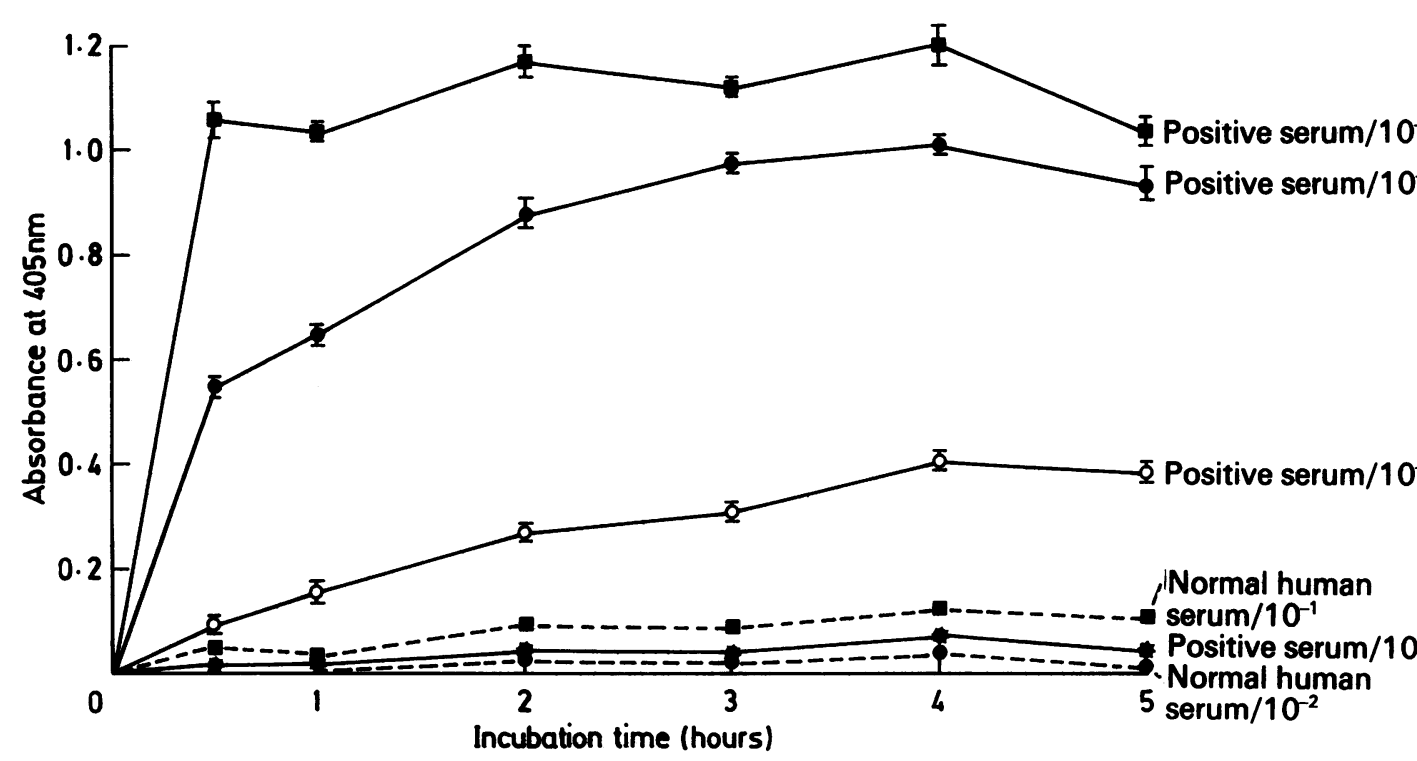

Fig 2 Kinetics of antibody binding to antigen-coated wells. Positive serum $10^{-1}-10^{-4}=$ known positive anti-glomerular antibody containing serum, 1 in 10 to 1 in 10000 dilutions. Normal human serum $10^{-1}$ and $10^{-2}$ at 1 in 10 and 1 in 100 dilutions.

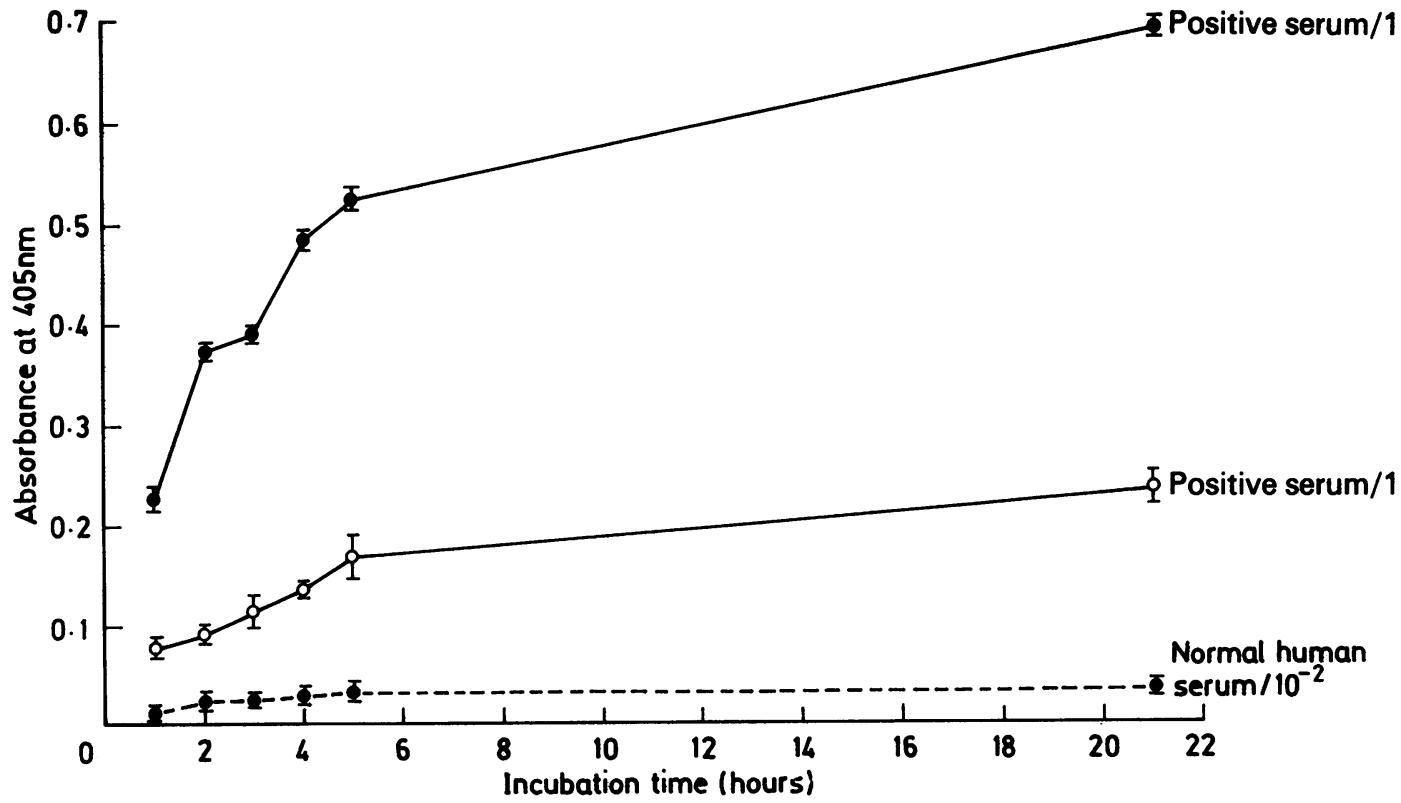

Fig 3 Kinetics of binding of enzyme linked anti-IgG to bound antigen-antibody complexes. Positive serum $10^{-2}$ and $10^{-3}$ $=$ known positive anti-glomerular basement membrane antibody containing serum at 1 in 100 and 1 in 1000 dilutions. Normal human serum at $10^{-2}=1$ in 100 dilution. 


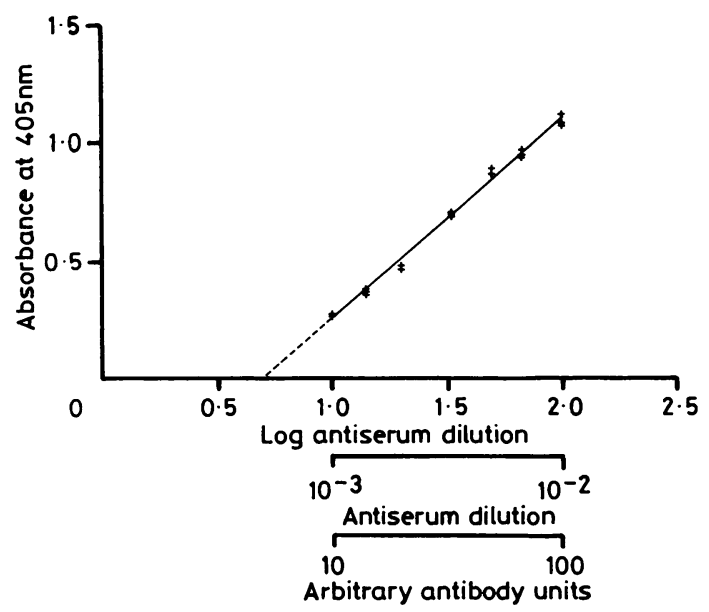

Fig 4 Calibration curve for measurement of anti-glomerular basement membrane antibodies.

reduced by $30 \%$, a similar reduction to that achieved by Stemshorn et al, ${ }^{15}$ by allocating duplicates to opposite plate quadrants.

\section{COMPARISON OF TUBE ELISA AND ROUTINE}

(OPTIMAL) PLATE ELISA

As the original tube ELISA was quantitated in the same way the tube ELISA was compared with the routine plate ELISA, by assaying in plates, sera which had been assayed previously in tubes against the positive serum standard. Forty three sera were assayed: 24 positive anti-glomerular basement membrane sera with activities ranging from 11.5 to $>100$ arbitrary antibody units and 19 negative sera, all with activities of $<7$ arbitrary antibody units. The 19 negative sera were confirmed negative by the plate technique and the 24 positive sera gave activities ranging from 8.7 to $>100$ arbitrary antibody units. The comparison of the 24 positive sera is shown in fig 5. The diagonal line is the theoretical line of equivalence and a paired $t$ test showed no significant bias between the two techniques.

\section{ROUTINE ASSAY OF TEST SERA}

With the routine (optimal) ELISA, 238 sera from 200 patients with various types of renal disease have been examined in the past year, including mesangial proliferative glomerulonephritis, Henoch-Schonlein purpura, minimal change glomerulonephritis, membranous glomerulonephritis, proliferative glomerulonephritis, polyarteritis nodosa, Wegener's granulomatosus, diabetes, amyloid, hypertension, membrano-proliferative glomerulonephritis, and antiglomerular basement membrane disease. In addition, sera from normal controls, with no history of renal disease, were also assayed. Sera from normal controls and all groups of patients, except those with active anti-glomerular basement membrane disease, had anti-glomerular basement membrane activities of $<7$ arbitrary antibody units. In strong contrast, those patients with active anti-glomerular basement membrane disease had activities ranging from 12.9 arbitrary antibody units to $>100$ arbitrary antibody units.

In total, 31 sera from 10 patients in various stages of anti-glomerular basement membrane disease have been assayed. Seven sera from three patients were positive (12.9-> 100 arbitrary antibody units); the remaining 24 sera from eight patients (one patient was common to both groups) were negative ( $<7$ arbitrary antibody units) and were all taken either after nephrectomy or extensive treatment.

\section{REPRODUCIBILITY OF ROUTINE (OPTIMAL) PLATE} ELISA

To assess the reproducibility of the routine plate ELISA technique normal human serum and 10 positive sera were assayed weekly for three weeks in freshly coated plates against standard serum. Each week three identical plates were set up and, within each plate in adjacent wells of a column, each serum was assayed in triplicate. Intra- and interassay coefficients of variation were calculated and the results are shown in table 1 .

Intra-assay CVs ranged from 1.0 to $2.8 \%$ (mean $1.6 \%$ ). The CV between plates assayed on the same day increased with the mean antiglomerular basement membrane antibody activity. It was similar to the intra-assay $\mathrm{CV}$ up to about the middle of the standard

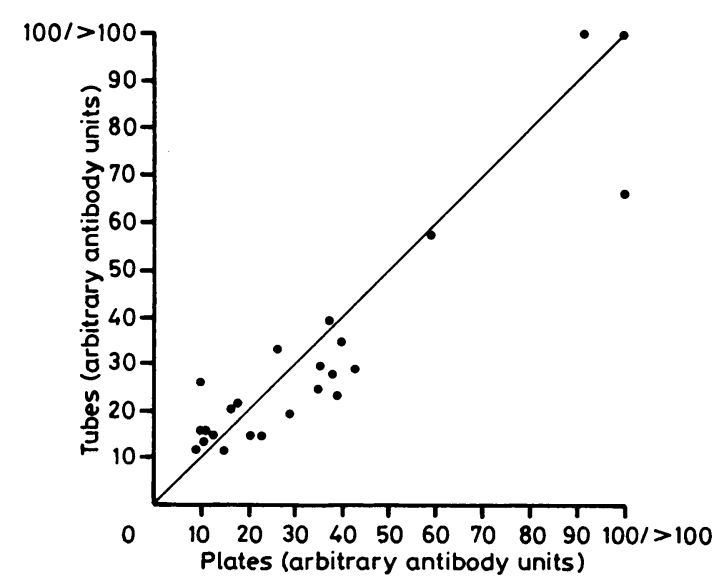

Fig 5 Comparison of anti-glomerular basement membrane antibody titres by tube ELISA and routine plate ELISA techniques. 
Table 1 Intra-and interassay coefficients of variation (\%)

\begin{tabular}{|c|c|c|c|}
\hline \multirow{2}{*}{$\begin{array}{l}\text { Mean anti-glomerular } \\
\text { basement membrane } \\
\text { antibody activity } \\
\text { arbitrary antibody } \\
\text { units }\end{array}$} & \multirow{2}{*}{$\begin{array}{l}\text { Intra-assay: } \\
\text { Between } \\
\text { triplicates }\end{array}$} & \multicolumn{2}{|c|}{ Interassay: } \\
\hline & & $\begin{array}{l}\text { Between } \\
\text { plates }\end{array}$ & $\begin{array}{l}\text { Between } \\
\text { weeks }\end{array}$ \\
\hline $\begin{array}{l}\text { Normal human serum } \\
(6 \cdot 8)\end{array}$ & 2.6 & 1.3 & $2 \cdot 0$ \\
\hline 10 & $1 \cdot 0$ & 0.9 & 1.0 \\
\hline 12 & 1.5 & $1 \cdot 0$ & 2.6 \\
\hline 13 & $1 \cdot 1$ & $1 \cdot 2$ & 0.4 \\
\hline 24 & 1.8 & 1.4 & $3 \cdot 1$ \\
\hline 26 & $2 \cdot 0$ & $2 \cdot 0$ & 1.5 \\
\hline 31 & 1.4 & $2 \cdot 2$ & 3.0 \\
\hline 74 & $2 \cdot 1$ & $3 \cdot 2$ & 0 \\
\hline 86 & $1 \cdot 7$ & $4 \cdot 6$ & 0 \\
\hline 94 & $1 \cdot 1$ & 3.0 & 0 \\
\hline 110 & $2 \cdot 8$ & 4.9 & 0 \\
\hline
\end{tabular}

curve, but for high readings, the between plates $\mathrm{CV}$ was about twice as large. Using a standard curve on every plate should minimise the variability between plates. We put the higher concentrations nearer the edge of the plate, which means they are more susceptible to edge effect; there is therefore more variability in the higher end of the standard curve from one plate to another. In routine use this is acceptable because the sera are still clearly abnormal. There is no additional week to week variability for these high titre sera because the plate to plate variability within a week is so high but, for the lower titre sera, all three sources of variation have about the same $\mathrm{CV}$.

To test whether it was necessary to use freshly coated plates five plates were coated with antigen under optimal conditions and stored at $4^{\circ} \mathrm{C}$ in covered incubation trays. Three plates were used one week later and the two others were stored for two weeks. The $\log _{10}$ (anti-glomerular basement membrane antibody activity) readings were then compared with those from three freshly coated plates assayed on the same day. No significant effect of storage for one week was detected, or of storage for two weeks for the seven lowest titre sera. The results from the stored plates were significantly lower for the four very high titres, but this appeared to be because the standard curve on both plates had a greater slope than usual. Although the differences were significant, they were not clinically important as the readings were still very high.

\section{RAPID ELISA METHOD}

As the rapid diagnosis of anti-glomerular basement membrane antibodies is of clinical importance shorter incubation times were also evaluated. Six rapid assays were investigated, in which the incubation times of various stages of the assay were reduced to one hour, 30 minutes, or 15 minutes, using either plates freshly coated with antigen for the reduced time, or plates coated under optimal conditions and stored at $4^{\circ} \mathrm{C}$ for
Table 2 Assay incubation times (hours) for routine and rapid ELISA techniques

\begin{tabular}{|c|c|c|c|c|c|}
\hline Assay & Antigen & Antibody & Conjugate & Substitute & $\begin{array}{l}\text { Total } \\
\text { time }\end{array}$ \\
\hline $\begin{array}{l}\text { Routine } \\
\text { Routine } \\
\text { Rapid- } 1 \\
2 \\
3 \\
4 \\
5 \\
6\end{array}$ & $\begin{array}{l}3 \\
\text { Stored } \\
\text { Stored } \\
1 \\
\text { Stored } \\
0 \cdot 5 \\
\text { Stored } \\
0.25\end{array}$ & $\begin{array}{l}2 \\
2 \\
1 \\
1 \\
0.5 \\
0.5 \\
0.25 \\
0.25\end{array}$ & $\begin{array}{l}\sim 17 \\
\sim 17 \\
1 \\
1 \\
0.5 \\
0.5 \\
0.25 \\
0.25\end{array}$ & $\begin{array}{l}0.25 \\
0.25 \\
0.5 \\
0.5 \\
0.5 \\
0.5 \\
0.67 \\
0.67\end{array}$ & $\begin{array}{c}\sim 22.25 \\
\sim 19.25 \\
2.5 \\
3.5 \\
1.5 \\
2.0 \\
1.17 \\
1.42\end{array}$ \\
\hline
\end{tabular}

up to one week. The assay conditions for these six rapid ELISAs are outlined in table 2 and the assays have been coded 1-6. The effect of the reduced incubation times is shown in fig 6: 10 standard curves from the routine (optimal) ELISA, using either freshly coated or stored plates, were compared with the standard curves 1-6 from the appropriate rapid ELISA. The results show a considerable decrease in the gradients of all six rapid ELISA standard curves compared with those of the routine (optimal) ELISA. The gradient also decreased as the total assay time was reduced within the six rapid ELISAs.

The net effect of this on the measurement of normal human serum and a range of 15 positive sera was evaluated. The sera were assayed at dilutions of 1 in 100 and 1 in 10 in the routine and rapid ELISAs, and the results of normal human serum and three representative sera are shown in fig 7. In all six rapid ELISAs the 15 positive sera gave a level of discrimination similar to that observed in the routine assay, with no false positive or false negative results.

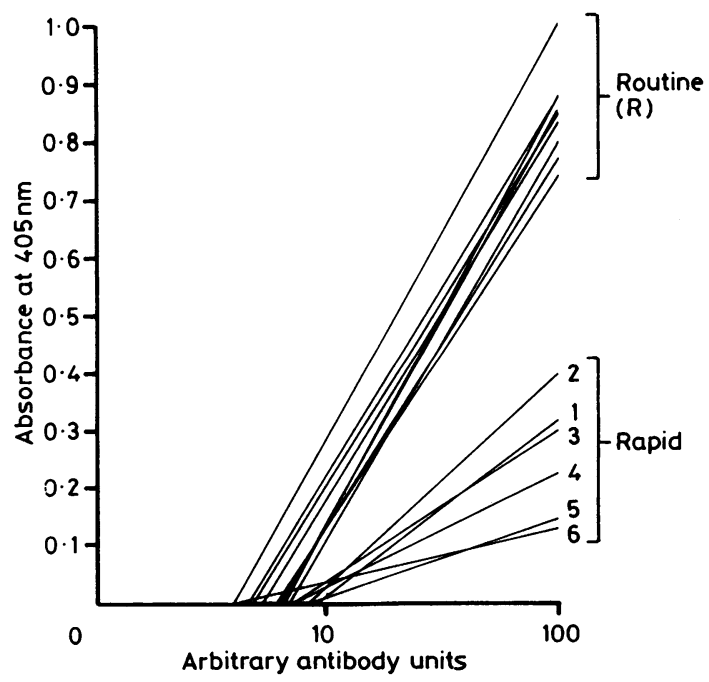

Fig 6 Calibration curves for routine $(R)$ and six rapid ELISA techniques (1-6). 


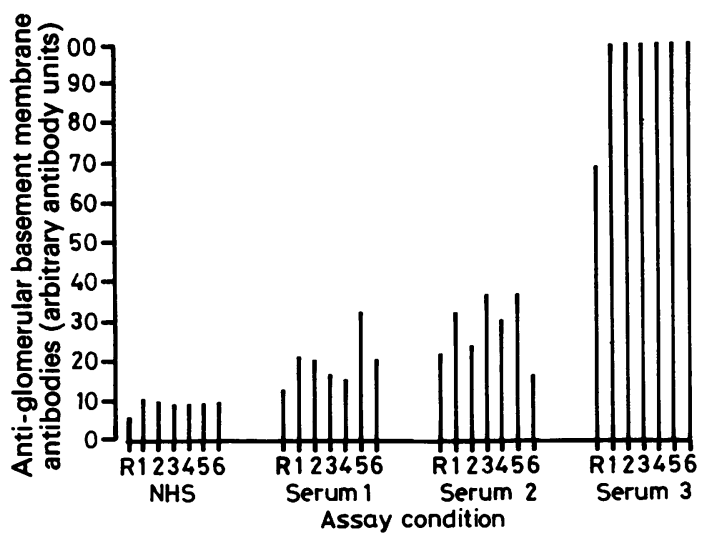

Fig 7 Routine ( $R$ ) and rapid (1-6) ELISA results for normal human serum (NHS) and three positive antiglomerular basement membrane sera (serum 1, 2,3).

\section{Discussion}

During the past decade ELISA has become a generally accepted method for the detection and quantitation of antibodies, as it has been found to be as sensitive as the corresponding radioimmunoassay, with the added advantage of fewer requirements for specialised equipment. The main problem with ELISA, however, as with other solid phase assays, is the difficulty encountered in controlling coating of the antigen to plastic. Different antigens will coat with different efficiencies, which can result in a minimal coating of the proteins under investigation. An additional problem is the release of antigen during assay, which gives rise to some of the variations seen in ELISA.

The specificity of any ELISA depends on the antigen preparation used for coating the solid phase. Antigens solubilised by collagenase have been widely used in assays for anti-glomerular basement membrane antibodies, ${ }^{8-11}$ because these antigens give an assay that is rather selective for antibodies from sera of patients with Goodpasture's syndrome, while sera from patients with other glomerulonephropathies show little reactivity. ${ }^{10}$ In this assay $150 \mu \mathrm{l}$ of collagenase-digested glomerular basement membrane, of protein concentration $10 \mu \mathrm{g} / \mathrm{ml}$, gave sufficient coating of specific antigen.

The sensitivity of any ELISA depends on both the solid phase used and the background reactivity. The importance of the solid phase has been well illustrated by Weber et al, ${ }^{11}$ who tested 22 different types of microtitre plate for suitability in an ELISA for antiglomerular basement membrane antibodies, using collagenase-digested glomerular basement membrane as antigen. In their study Dynatech flexible PVC microtitre plates with flat wells (code M29) gave the highest positive serum:negative serum ratio and, moreover, repeated analysis of the same serum sample on all plates showed that the PVC plate with flat wells exhibited the lowest standard deviation.

Assay sensitivity is also affected by non-specific binding of immunoglobulins or enzyme conjugated antibodies to the plastic wells, or to the protein coat of the wells, thereby causing an increase in background absorbances and a decrease in assay sensitivity. This background is considerably reduced by the inclusion of Tween 20 in the various stages of the assay. Furthermore, the study of Weber et al ${ }^{\prime \prime}$ showed that Dynatech PVC microtitre plates gave the lowest background absorbances, indicating an optimal suppression of non-specific binding of immunoglobulins or conjugate.

The results in table 1 show that there is little variability between triplicates in adjacent wells in a column on a plate, indicating that duplicates would suffice. Our uniformity experiments showed that the worst of the edge effect is removed by using only the inner 60 wells of a plate. This is simple and convenient for routine assays of only a few unknown sera, but would be inefficient for large numbers of patients. For large scale routine use it would be desirable to use all 96 wells, with a standard curve on every plate, all measurements made in duplicate, with edge effects controlled by systematic location of the duplicates, using a design such as that proposed by Stemshorn et al. ${ }^{15}$

In this paper we have described an assay for the detection and quantitation of circulating antiglomerular basement membrane antibodies, which is both sensitive and reproducible and which, under optimal conditions, requires a total assay time of about 24 hours. The test has been used routinely for the examination of 238 sera from 200 patients, and circulating anti-glomerular basement membrane antibodies have been detected in seven sera from three patients with active anti-glomerular basement membrane disease. No false positive or negative results have been found. To date, too few patients have been studied to show any significant difference in the titres of anti-glomerular basement membrane antibodies in patients with Goodpasture's syndrome compared with those with renal disease alone. In the case of one patient, however, the assay has been useful in monitoring a reduction in the antibody titre during treatment.

Finally, we wish to emphasise the potential value of the rapid ELISA, which, when necessary, can be performed in less than four hours and from which both high and low titre anti-glomerular basement membrane sera can be confidently diagnosed.

We are indebted to the Northern Counties Kidney Research Fund and the District Research Committee 
of Newcastle Health Authority for financial support. We also thank Mrs Linda Wragg and Mrs Susan Stamp for technical assistance and Mrs Jan Mackay for typing the manuscript.

\section{References}

1 McPhaul JJ, Dixon FJ. The presence of anti-glomerular basement membrane antibodies in peripheral blood. $J$ Immunol 1969;103:1168-75.

2 Macanovic M, Evans DJ, Peters DK. Allergic response to glomerular basement membrane in patients with glomerulonephritis. Lancet 1972;ii:207-10.

3 Mahieu P, Dardenne M, Bach JF. Detection of humoral and cellmediated immunity to kidney basement membranes in human renal diseases. Am J Med 1972;53:185-92.

4 Wilson CB, Dixon FJ. Anti-glomerular basement membrane antibody-induced glomerulonephritis. Kidney Int 1973;3:74-89.

5 Mahieu P, Lambert PH, Maghuin-Rogister G. Primary structure of a small glycopeptide isolated from human glomerular basement membrane and carrying a major antigenic site. Eur J Biochem 1973;40:599-606.

6 Wilson CB, Dixon FJ. Diagnosis of immunopathologic renal disease. Kidney Int 1974;5:389-401.

7 Buffaloe GW, Tavel TB, McIntosh RM, Glassock RJ, Terman DS. Antibodies to human glomerular basement membrane (GBM): new methodology for detection in human sera. Kidney Int 1978;14:707.

8 Wheeler J, Sussman M. Enzyme-linked immunosorbent assay for circulating anti-glomerular basement membrane antibodies. Clin Exp Immunol 1981;45:271-8.

9 Wieslander J, Bygren PG, Heinegard D. Antibasement membrane antibody: Immunoenzymatic assay and specificity of antibodies. Scand J Clin Lab Invest 1981;41:763-72.

10 Wieslander J, Bygren PG, Heinegard D. Antiglomerular basement membrane antibody: Antibody specificity in different forms of glomerulonephritis. Kidney Int 1983;23:855-61.

11 Weber M, Kohler H, Manns M, Meyer zum Buschenfelde K-H. Antiglomerular basement membrane antibodies in human sera: Detection by a modified micro-ELISA. Clin Immunol Immunopathol 1985;35:285-94.

12 Gomori G. Preparation of buffers for use in enzyme studies: In: Colowick SP, Kaplan NO, eds. Methods in enzymology. New York: Academic Press, 1955:138.

13 Hartree EF. Determination of protein: a modification of the Lowry method that gives a linear photometric response. Anal Biochem 1972;48:422-7.

14 Wheeler J, Holland J, Menzies S, Blainey JD. Immunological response to glomerular basement membrane and streptococcal antigens in immunized rabbits. Immunology 1975;28:653-8.

15 Stemshorn BW, Buckley DJ, St Amour G, Lin CS, Duncan JR. A computer-interfaced photometer and systemic spacing of duplicates to control within-plate enzyme-immunoassay variation. J Immunol Methods 1983;61:367-75.

Requests for reprints to: Dr Janice Wheeler, Department of Pathology, Royal Victoria Infirmary, Newcastle upon Tyne NE1 4LP, England. 